\title{
Soil type determines the abundance and community structure of ammonia-oxidizing bacteria and archaea in flooded paddy soils
}

\author{
Xin Chen • Li-Mei Zhang • Ju-Pei Shen • Zhihong Xu • \\ Ji-Zheng He
}

Received: 25 April 2010 /Accepted: 12 May 2010 /Published online: 15 June 2010

(C) Springer-Verlag 2010

\begin{abstract}
Purpose Ammonia oxidation plays an important role in global nitrogen cycle. However, little information is available on ammonia oxidizers in paddy soils. This study aimed to understand the controlling factors of ammonia oxidizers in the paddy soils.

Materials and methods Three types of paddy soils were collected from southwest [Chongqing City (CQ)], central [Honghu City (HH)], and northeast [Panjin City (PJ)] of China, respectively. The soils were cultured with unplanted and rice-planted pot experiments for 10 weeks. The abundance and composition of ammonia-oxidizing bacteria (AOB) and ammonia-oxidizing archaea (AOA) of the paddy soil samples were investigated by real-time polymerase chain reaction and denaturing gradient gel electrophoresis approaches based on amoA genes.

Results and discussion In this study, minor changes in the abundance and community structure of both AOB and AOA were observed among the treatments of unplanted and rhizosphere and bulk of rice-planted soil samples in the
\end{abstract}

Responsible editor: Hailong Wang

X. Chen · L.-M. Zhang · J.-P. Shen · J.-Z. He $(\bowtie)$

State Key Laboratory of Urban and Regional Ecology, Research

Center for Eco-Environmental Sciences,

Chinese Academy of Sciences,

Beijing 100085, People's Republic of China

e-mail: jzhe@rcees.ac.cn

X. Chen

Graduate University, Chinese Academy of Sciences,

Beijing 100049, People's Republic of China

\section{Z. Xu}

Environmental Futures Centre and School of Biomolecular and Physical Sciences, Griffith University,

Nathan, Queensland 4111, Australia same type of paddy soil. The AOB population sizes in CQ were lower than those in $\mathrm{HH}$ and PJ, while the AOA in CQ and $\mathrm{HH}$ were lower than those in PJ. The amoA gene copy numbers of AOA were more abundant than those of AOB in all treatments of the three paddy soils. The community structure of both AOB and AOA in all paddy soils was different from each other.

Conclusions The population size and community structure of $\mathrm{AOB}$ and AOA in the flooded paddy soils were mainly determined by the soil types, irrespective of rice-planted or unplanted.

Keywords Ammonia-oxidizing archaea $\cdot$ Ammoniaoxidizing bacteria $\cdot$ Denaturing gradient gel electrophoresis · Nitrogen cycle $\cdot$ Paddy soil $\cdot$ Real-time PCR

\section{Introduction}

Ammonia oxidation is the first and rate-limiting step of nitrification and plays a key role in global nitrogen cycle. This process was typically thought to be carried out by ammonia-oxidizing bacteria (AOB). Until recently, metagenomic studies demonstrated the potential of ammonia oxidation by mesophilic Crenarchaeota and revealed the presence of ammonia monooxygenase gene derived from the Crenarchaeota (Venter et al. 2004; Könneke et al. 2005; Treusch et al. 2005). Ammonia monooxygenase (AMO), the key functional enzyme responsible for the autotrophic ammonia oxidation, is encoded by the genes amo $A, B$, and $C$. Increasing evidence showed that ammonia-oxidizing archaea (AOA) can be detected in various habitats, such as marine water columns (Francis et al. 2005; Wuchter et al. 2006), sediments (Beman and 
Francis 2006), estuaries (Mosier and Francis 2008), hot springs (Weidler et al. 2007), and soils (Leininger et al. 2006; He et al. 2007; Shen et al. 2008; Schauss et al. 2009) and may be another major microbial group involved in the ammonia oxidation besides AOB.

Irrigated paddy field is a typical wetland habitat in terrestrial ecosystems, which has served as a useful model for biogeochemistry and microbiology studies. Owing to rice roots releasing $\mathrm{O}_{2}$, the paddy soil forms a unique environment: the rhizosphere is partially oxic, while the bulk soil is anoxic (Revsbech et al. 1999). This may lead to the different distribution of $\mathrm{AOB}$ and AOA communities in rhizosphere and bulk soil. However, limited information is available on ammonia-oxidizing organisms in paddy soils, especially in different types of paddy soils. Some researchers have proposed that soil type is the primary determinant of the bacterial community composition in arable soils (Girvan et al. 2003), but no information is available about the effect of soil types on $\mathrm{AOB}$ and AOA abundance and community structure in paddy soils.

In this study, we hypothesized that: (1) rice planting could result in the shifts of $\mathrm{AOB}$ and AOA population size and community structure in the flooded paddy soils; (2) different types of paddy soils could have different abundance and community structure of ammonia oxidizers. In order to test these hypotheses, we used three types of paddy soils in pot experiments with three treatments of unplanted, rhizosphere, and bulk of rice-planted. Realtime polymerase chain reaction (qPCR) and denaturing gradient gel electrophoresis (DGGE) approaches based on amoA genes were used to characterize the abundance and community composition of $\mathrm{AOB}$ and $\mathrm{AOA}$ in the paddy soil samples.

\section{Materials and methods}

\subsection{Original soil samples and pot experiment}

Original paddy soil samples $(0-20 \mathrm{~cm})$ were collected from three different regions of China including purple paddy soil from Chongqing City (CQ, N29.83, E106.43 ${ }^{\circ}$ ), southwestern China; alluvial paddy soil from Honghu City (HH, N29.48 ${ }^{\circ}$ E113.27 $)$, Hubei Province, central China; and coastal saline paddy soil from Panjin City (PJ, N41.12 ${ }^{\circ}, \mathrm{E} 122.06^{\circ}$ ), Liaoning Province, northeastern China. The $\mathrm{pH}$ values of these paddy soils were $8.2,7.6$, and 8.1 , respectively.

Polyvinyl chloride pots $(18 \mathrm{~cm}$ diameter, $20 \mathrm{~cm}$ height) were used in this experiment. Each soil was prepared for two treatments with three replicates: one treatment was rice-planted and the other unplanted. The rice-planted treatment was further divided into bulk and rhizosphere compartments with a root bag $(37 \mu \mathrm{m}$ nylon mesh, $5 \mathrm{~cm}$ diameter, $10 \mathrm{~cm}$ height, and one plant per bag). Each pot was filled with $3 \mathrm{~kg}$ of air-dried soil including $0.2 \mathrm{~kg}$ soil in the root bag. The pots were maintained for waterlogging with deionized water (water depth 3 to $4 \mathrm{~cm}$ above the soil surface) until harvest.

Rice seeds (Oryza sativa L.) cv. Jiahua-1 were pretreated and germinated as described in previous paper (Chen et al. 2008). After 3 weeks, uniform seedlings were picked out from water culture and transplanted into the pots. Then, the rice plants were cultivated for 10 weeks in a greenhouse where the temperature was kept at $25^{\circ} \mathrm{C}$ during the day and $16^{\circ} \mathrm{C}$ during the night, with $14 / 10 \mathrm{~h}$ light/dark cycle and $70 \%$ relative humidity.

\subsection{Sample collection}

The rice plants were harvested after 10 weeks, and soil samples were collected from each treatment. All the samples were divided into two parts: one was stored at $4^{\circ}$ $\mathrm{C}$ for chemical analyses and the other frozen at $-80^{\circ} \mathrm{C}$ for subsequent DNA extraction and molecular analyses.

\subsection{Chemical analyses}

Soil $\mathrm{pH}$ of the pot experiments was measured in situ with an automatic redox potential device (FJA-3 type, China) before sample collection. Soil ammonium and nitrate contents were extracted from fresh soil samples with $2 \mathrm{M} \mathrm{KCl}$ and determined by a continuous flow analyzer (SAN++, Skalar, Holland).

\subsection{Molecular analyses}

DNA was extracted from $0.5 \mathrm{~g}$ frozen paddy soil sample using UltraClean ${ }^{\mathrm{TM}}$ Soil DNA Isolation Kit (MoBio Laboratory, USA). The extracted DNA was checked on $0.8 \%$ agarose gel, and the concentration was determined with spectrophotometry (NanoDrop, USA).

The quantification of amoA gene copies was conducted on an iCycler iQ5 Thermocycler (Bio-Rad, USA) with the fluorescent dye SYBR-Green I (Zhang et al. 2009). Amplification was performed in $25-\mu l$ reaction mixtures, including $12.5 \mu \mathrm{l}$ SYBR $^{\circledR}$ Premix Ex Taq ${ }^{\mathrm{TM}}$ (Takara Biotechnology, Japan), $1 \mu$ l bovine serum albumin $\left(25 \mathrm{mg} \mathrm{ml}^{-1}\right), 0.5 \mu \mathrm{l}$ each primer $(10 \mu \mathrm{M})$ listed in Table 1 and $2 \mu \mathrm{l}$ DNA template $(1-10 \mathrm{ng})$. The standards and the DNA samples were performed on the same plate. The data were analyzed with the $\mathrm{iQ}^{\mathrm{TM}} 5$ software (Bio-Rad, USA).

The PCR for DGGE analysis was performed with the primer pairs containing a 40 base GC-clamp in one primer 
Table 1 Primers used for the real-time PCR and PCR-DGGE analyses

\begin{tabular}{lllcl}
\hline Target group & Primer & Sequence(5'-3') & Length of amplicon (bp) & Reference \\
\hline AOB & amoA1F & GGGGTTTCTACTGGTGGT & 491 & Rotthauwe et al. 1997 \\
& GC -amoA1F & & & \\
& amoA2R & CCCCTCKGSAAAGCCTTCTTC & Francis et al. 2005 \\
AOA & Arch-amoAF & STAATGGTCTGGCTTAGACG & 635 & \\
& Arch-amoAR & GCGGCCATCCATCTGTATGT & & \\
& GC -Arch-amoAR & & & \\
\hline
\end{tabular}

a (CGCCCGCCGCGCCCCGCGCCCGTCCCGCCGCCCCCGCCCG)

b (CGCCCGCCGCGCCCCGCGCCCGGCCCGCCGCCCCCGCCCC)

(see Table 1). The $50-\mu 1$ reaction mixtures consisted of $5 \mu 1$ $10 \times$ PCR buffer $\left(\mathrm{Mg}^{2+}\right.$ plus), $4 \mu \mathrm{l} 2.5 \mathrm{mM}$ dNTPs, $0.5 \mu \mathrm{l}$ Ex Taq HS polymerase (5U $\mu \mathrm{l}^{-1}$, Takara Biotechnology, Japan), $1 \mu$ l of each primer, and $2 \mu$ DNA template (1-10 ng). A touchdown PCR strategy was used for amplification of bacterial and archaeal amo $A$ gene fragments. The thermal cycle parameters of the touchdown PCR employed were as follows: an initial denaturation step at $95^{\circ} \mathrm{C}$ for $3 \mathrm{~min}$; followed by a touchdown procedure (including $30 \mathrm{~s}$ at $95^{\circ} \mathrm{C}$, annealing for $45 \mathrm{~s}$ at temperatures decreasing from $60^{\circ} \mathrm{C}$ to $55^{\circ} \mathrm{C}$ during the first ten cycles, and ending with an extension step at $72^{\circ} \mathrm{C}$ for $1 \mathrm{~min}$ ); and then 30 additional cycles of $94^{\circ} \mathrm{C}$ for $30 \mathrm{~s}, 55^{\circ} \mathrm{C}$ for $45 \mathrm{~s}$, $72^{\circ} \mathrm{C}$ for $1 \mathrm{~min}$; and finally, an extension of $10 \mathrm{~min}$ at $72^{\circ} \mathrm{C}$.

DGGE analysis was carried out in a DCode universal mutation detection system (Bio-Rad Laboratories, Hercules, USA). The PCR products of bacterial and archaeal amo $A$ genes were separated on a $6 \%(w / v)$ polyacrylamide gel, using a denaturing gradient of $40-65 \%$ and $25-50 \%$ ( $100 \%$ denaturant contains $7 \mathrm{M}$ urea and $40 \%$ formamide), respectively. After running, the gels were stained with 1:10,000 SYBR Gold nucleic acid gel stain (Invitrogen 20 Molecular Probes, Eugene, USA) for $30 \mathrm{~min}$ and then scanned by a GBOX/HR-E-M (Syngene, UK). The results were analyzed using the Quantity One (Bio-Rad Laboratories) software. Correspondence analysis (CA) for community ordination was conducted by CANOCO for
Windows version 4.5 using relative band intensity data from the Quantity One analysis results. The data were log $(\mathrm{x}+1)$-transformed before CA.

\subsection{Statistical analysis}

The data obtained from this study were statistically analyzed using ANOVA with SPSS for Windows. The significant differences were detected at level of $P<0.05$, and $\mathrm{S}-\mathrm{N}-\mathrm{K}$ test was performed to check for quantitative differences between different treatments.

\section{Results}

\subsection{Soil chemical properties}

After 10 weeks of cultivation, $\mathrm{pH}$ values in all soils were close to neutral ranging from 7.0 to 7.7 (Table 2). Soil pH values were varied among the treatments from the same paddy soil and found in order of unplanted $>$ bulk riceplanted $>$ rhizosphere rice-planted. With different types of paddy soils, the $\mathrm{pH}$ values of the treatments of PJ unplanted and bulk rice-planted soils were higher than those of $\mathrm{CQ}$ and $\mathrm{HH}$, but for the rhizosphere rice-planted treatments, there were no significant differences among the soils and the $\mathrm{pH}$ values were 7.0. The contents of $\mathrm{NH}_{4}{ }^{+}-\mathrm{N}$ were
Table 2 Chemical properties of the paddy soils at the end of 10 -week pot experiment

${ }^{\mathrm{a}}$ Treatment: $\mathrm{n}$ unplanted, $\mathrm{r}$ and $\mathrm{b}$ rhizosphere and bulk rice-planted samples, respectively. Values are mean \pm SD $(n=3)$. Values within the same column followed by the different letters are significantly different $(P<0.05)$

\begin{tabular}{lllcc}
\hline Region & Treatment $^{\mathrm{a}}$ & $\mathrm{pH}$ & $\mathrm{NH}_{4}{ }^{+}-\mathrm{N}\left(\mathrm{mg} \mathrm{kg}^{-1}\right)$ & $\mathrm{NO}_{3}{ }^{-}-\mathrm{N}^{\left.-\mathrm{mg} \mathrm{kg}^{-1}\right)}$ \\
\hline $\mathrm{CQ}$ & $\mathrm{n}-\mathrm{CQ}$ & $7.4 \pm 0.1 \mathrm{c}$ & $370 \pm 6 \mathrm{f}$ & $0.91 \pm 0.01 \mathrm{~cd}$ \\
& $\mathrm{r}-\mathrm{CQ}$ & $7.0 \pm 0.0 \mathrm{a}$ & $189 \pm 27 \mathrm{c}$ & $0.91 \pm 0.02 \mathrm{~cd}$ \\
& $\mathrm{~b}-\mathrm{CQ}$ & $7.3 \pm 0.0 \mathrm{~b}$ & $323 \pm 21 \mathrm{e}$ & $0.72 \pm 0.05 \mathrm{bc}$ \\
$\mathrm{HH}$ & $\mathrm{n}-\mathrm{HH}$ & $7.4 \pm 0.0 \mathrm{c}$ & $253 \pm 12 \mathrm{~d}$ & $0.87 \pm 0.01 \mathrm{~cd}$ \\
& $\mathrm{r}-\mathrm{HH}$ & $7.0 \pm 0.1 \mathrm{a}$ & $110 \pm 16 \mathrm{~b}$ & $0.88 \pm 0.07 \mathrm{~cd}$ \\
& $\mathrm{~b}-\mathrm{HH}$ & $7.2 \pm 0.1 \mathrm{~b}$ & $216 \pm 23 \mathrm{c}$ & $0.82 \pm 0.07 \mathrm{~cd}$ \\
$\mathrm{PJ}$ & $\mathrm{n}-\mathrm{PJ}$ & $7.7 \pm 0.1 \mathrm{~d}$ & $268 \pm 22 \mathrm{~d}$ & $1.00 \pm 0.05 \mathrm{~d}$ \\
& r-PJ & $7.0 \pm 0.1 \mathrm{a}$ & $45.1 \pm 13.2 \mathrm{a}$ & $0.65 \pm 0.16 \mathrm{~b}$ \\
& $\mathrm{~b}-\mathrm{PJ}$ & $7.5 \pm 0.1 \mathrm{c}$ & $187 \pm 16 \mathrm{c}$ & $0.50 \pm 0.12 \mathrm{a}$ \\
\hline
\end{tabular}


significantly different among the treatments of the same paddy soil (see Table 2). Likewise, there also existed changes in soil $\mathrm{NH}_{4}{ }^{+}-\mathrm{N}$ content among the different types of paddy soils. However, soil $\mathrm{NO}_{3}{ }^{-}-\mathrm{N}$ content did not vary much among the treatments except for the PJ paddy soil (see Table 2).

\subsection{Abundance of AOB and AOA in paddy soils}

The amoA gene copy numbers of $\mathrm{AOB}$ and $\mathrm{AOA}$ were assessed using qPCR. The bacterial $a m o A$ gene copy numbers in the soils ranged from $1.41 \times 10^{4}$ to $2.87 \times 10^{5}$ copies per gram dry soil, while the archaeal amoA gene copy numbers ranged from $3.95 \times 10^{6}$ to $2.87 \times 10^{7}$ copies per gram dry soil (Fig. 1). No significant differences in the abundance of $\mathrm{AOB}$ and AOA were detected among the treatments (unplanted, rhizosphere, and bulk of rice-planted) in each paddy soil (see Fig. 1). However, the AOB population size of the CQ soil was lower than those of HH and PJ. The AOA abundance in PJ was higher than those of CQ and HH. The ratios of AOA to AOB amoA gene copy numbers ranged from 22.9 to 667 in all treatments, indicating that the AOA population sizes among the treatments in the three paddy soils was higher than those of AOB.

\subsection{DGGE profiles of AOB and AOA communities} in the three types of paddy soils

The DGGE patterns of AOB and AOA showed little changes in the same type of paddy soil, regardless of the treatments of rice-planted or unplanted (Figs. 2a and 3a). However, some variations were observed among the different types of paddy soils in the DGGE patterns (see Figs. $2 \mathrm{a}$ and $3 \mathrm{a}$ ). The $\mathrm{CA}$ ordination diagram of $\mathrm{AOB}$ and AOA communities are shown in Figs. $2 b$ and $3 b$. The individual points on the two-dimensional biplot represented the communities of the different treatments in three types of paddy soils. The difference between the communities was the distance between the points on the ordination diagram (Yang and Crowley 2000). A comparison of the distances showed that both $\mathrm{AOB}$ and AOA communities from the same paddy soil had the most similar structure. However, the communities from the different types of paddy soils were the most dissimilar and separated into three distinct clusters (see Figs. 2b and $3 b$ ). The CA supported the visual observation of DGGE patterns, indicating that the different treatments did not influence AOB and AOA composition, while the different types of paddy soils did affect $\mathrm{AOB}$ and AOA community structure.

\section{Discussion}

In this study, we applied qPCR to quantify the abundance of $\mathrm{AOB}$ and $\mathrm{AOA}$ based on amoA genes in different types of paddy soils. Both AOB and AOA were detected in large numbers in all paddy soils of this study. Although rice roots could release oxygen through aerenchymatous tissue and some soil chemical properties in the rice-planted rhizosphere were different from the other treatments, we did not find that the abundance of $\mathrm{AOB}$ in the rhizosphere differed from those in the bulk rice-planted and unplanted treatments for the same paddy soil. These results were consistent with those of Chen et al. (2008) findings, but

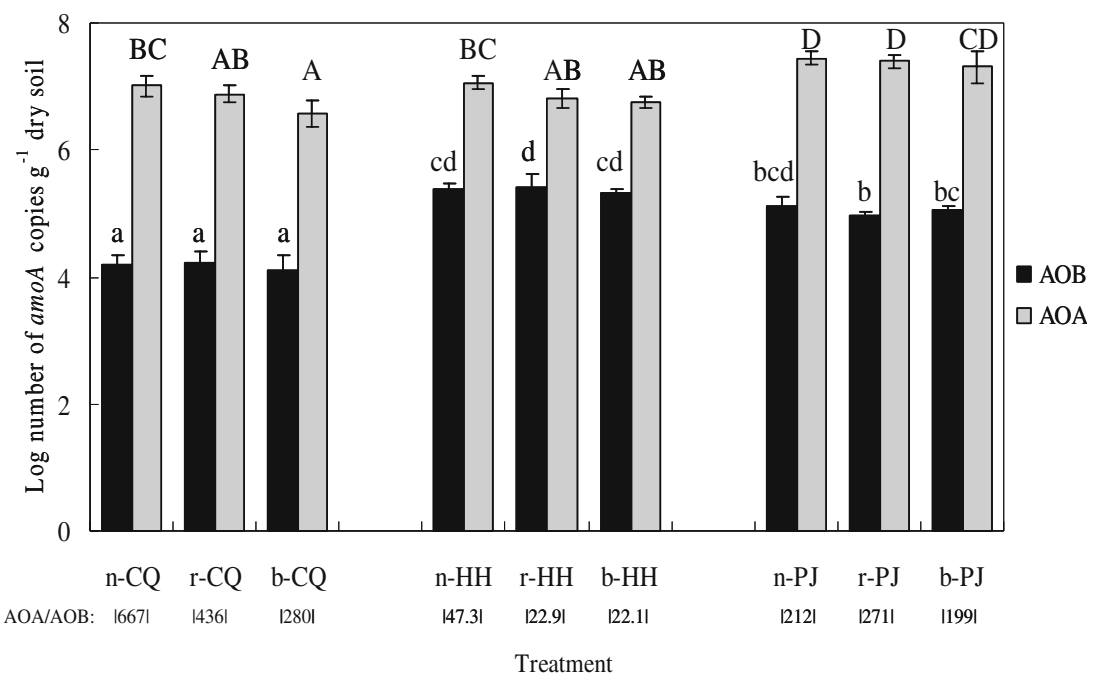

Fig. 1 The abundances of ammonia-oxidizing bacteria (AOB) and ammonia-oxidizing archaea (AOA) in different types of paddy soils $(\mathrm{CQ}, \mathrm{HH}$, and PJ) with the treatments of unplanted (n), rhizosphere (r), and bulk (b) of rice-planted samples. Error bars indicate standard deviations $(n=3)$. The different letters indicate significant differences $(P<0.05)$. Ratios of AOA to AOB amoA gene copy numbers are shown at the bottom of each treatment 

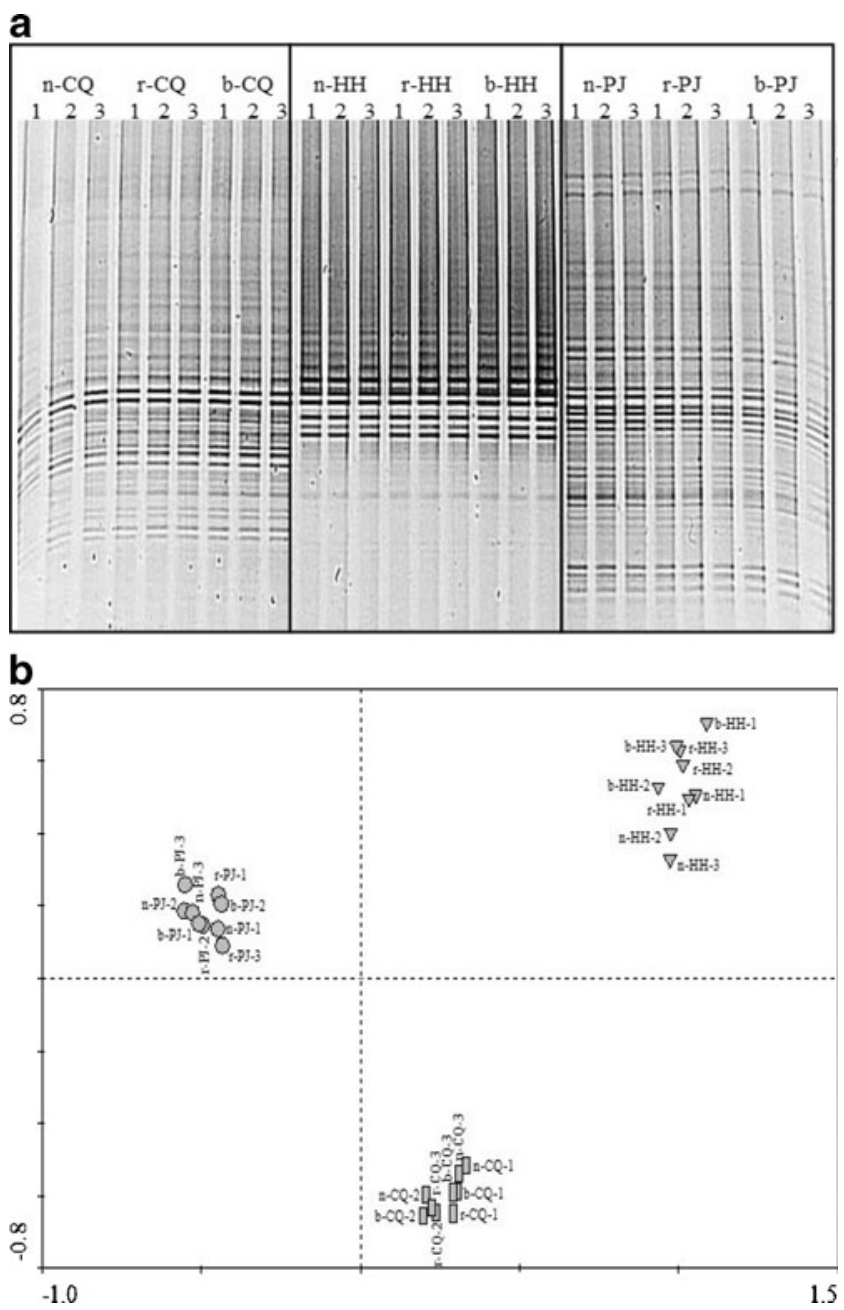

Fig. 2 (a) Denaturing gradient gel electrophoresis (DGGE) patterns of ammonia-oxidizing bacteria (AOB) with the treatments of unplanted (n), rhizosphere (r) and bulk (b) of rice-planted samples (CQ, HH and PJ). (b) Correspondence analysis (CA) ordination diagram of AOB communities generated by the AOB DGGE patterns

different from those of Nicolaisen et al. (2004) which found the abundance of AOB in rhizosphere was higher than that in the bulk soil. The reason for this inconsistency may be due to the near-neutral $\mathrm{pH}$ values of these three paddy soils which would favor the AOB growth. The growth of AOB was considered to be optimal at neutral to alkaline $\mathrm{pH}$ values (Prosser 1989). No significant differences were found in archaeal amoA gene copy number among the treatments for the same paddy soil despite of the lower oxygen concentrations in the bulk of rice-planted and unplanted treatments. Numerous studies have also reported high copy numbers of archaeal amoA gene in low oxygen environment (Park et al. 2006; Lam et al. 2007; Santoro et al. 2008). However, with different types of paddy soils of this study, there were some changes in the population size of both $\mathrm{AOB}$ and AOA. These results were similar to the previous study that three different ecological region soils

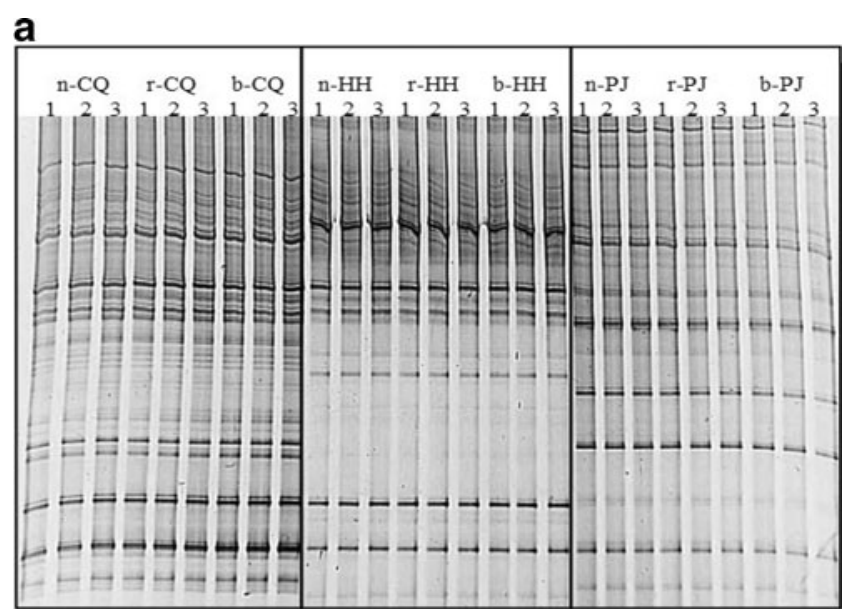

b

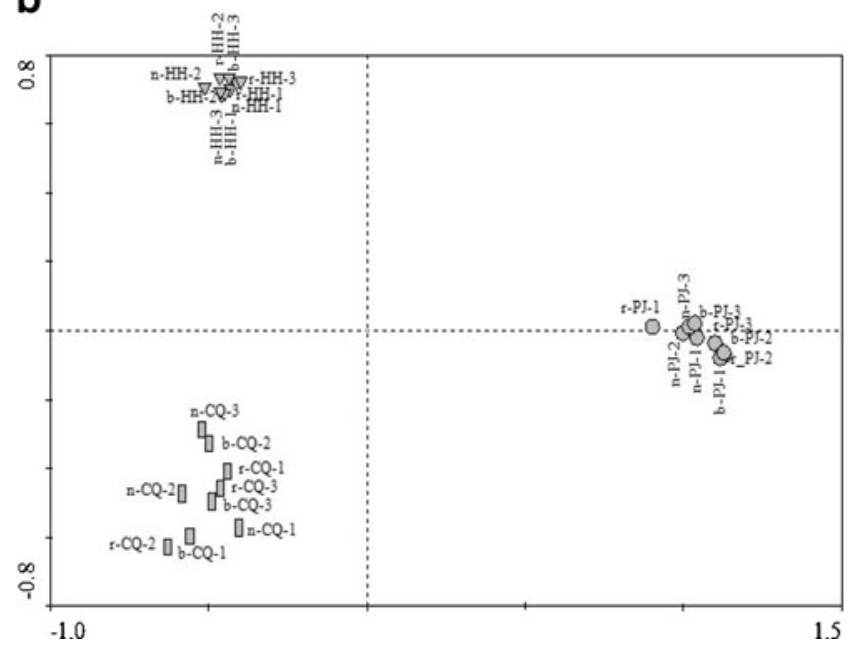

Fig. 3 a Denaturing gradient gel electrophoresis (DGGE) patterns of ammonia-oxidizing archaea (AOA) with the treatments of unplanted (n), rhizosphere (r) and bulk (b) of rice-planted samples (CQ, HH and $\mathrm{PJ})$. b Correspondence analysis (CA) ordination diagram of AOA communities generated by the AOA DGGE patterns

were characterized by a diverse population of AOB counted with the MPN-Griess method (Yuan et al. 2005). However, little information on the changes of AOA populations in the different soil types is reported. Our study showed that the AOA populations were different in different types of paddy soils, suggesting that soil types affected the abundance of AOA. Likewise, the high ratios of AOA to AOB were found in all samples, which were consistent with many related studies previously conducted in different ecosystems (Wuchter et al. 2006; He et al. 2007; Lam et al. 2007; Mincer et al. 2007; Shen et al. 2008; Ying et al. 2010), providing the evidence of AOA potential contribution to nitrification. However, recent studies also found that AOB amoA copy numbers were greater than those of AOA in some estuary and high altitude permafrost soils (Santoro et al. 2008; Zhang et al. 2009), and bacteria rather than archaea functionally dominate ammonia oxidation in 
pasture soils (Di et al. 2009, 2010). Thus, it is necessary to further study the function of $\mathrm{AOB}$ and $\mathrm{AOA}$ in the paddy soils.

The DGGE and CA ordination gave the intuitive results of $\mathrm{AOB}$ and AOA community structure. In our study, little difference in the community composition of $\mathrm{AOB}$ and AOA was detected among the treatments for each paddy soil. The AOB results were similar to those of Chen et al. (2008), while the AOA results were consistent with the recent research findings of Wang et al. (2009). However, the community shifts were detected among the different paddy soils, suggesting that both AOB and AOA compositions were mainly determined by the soil types. It was found that historical contingencies including soil type were the dominant factor driving variations in soil bacterial diversity (Ge et al. 2008).

In conclusion, our results showed that both $\mathrm{AOB}$ and AOA abundance and community structure changed little among the unplanted and rhizosphere and bulk of riceplanted treatments for the same paddy soil, but significant differences were observed among the three paddy soils, suggesting that different soil types affected the population and composition of $\mathrm{AOB}$ and $\mathrm{AOA}$ communities.

Acknowledgements This work was supported by the National Basic Research Program of China (2005CB121105) and the Natural Science Foundation of China (40871129, 50921064).

\section{References}

Beman JM, Francis CA (2006) Diversity of ammonia-oxidizing Archaea and bacteria in the sediments of a hypernutrified subtropical estuary: Bahiìa del Toibari, Mexico. Appl Environ Microbiol 72:7767-7777

Chen XP, Zhu YG, Xia Y, Shen JP, He JZ (2008) Ammonia-oxidizing Archaea: important players in paddy rhizosphere soil? Environ Microbiol 10:1978-1987

Di HJ, Cameron KC, Shen JP, Winefield CS, O'Callaghan M, Bowatte S, He JZ (2009) Nitrification driven by bacteria and not Archaea in nitrogen-rich grassland soils. Nature Geosci 2:621-624

Di HJ, Cameron KC, Shen JP, Winefield CS, O'Callaghan M, Bowatte S, He JZ (2010) Ammonia-oxidizing bacteria and Archaea grow under contrasting soil nitrogen conditions. FEMS Microbiol Ecol 72:386-394

Francis CA, Roberts KJ, Beman JM, Santoro AE, Oakley BB (2005) Ubiquity and diversity of ammonia-oxidizing Archaea in water columns and sediments of the ocean. Proc Natl Acad Sci USA 102:14683-14688

Ge Y, He JZ, Zhu YG, Zhang JB, Xu ZH, Zhang LM, Zheng YM (2008) Differences in soil bacterial diversity: driven by contemporary disturbances or historical contingencies? ISME J 2:254-264

Girvan MS, Bullimore J, Pretty JN, Osborn AM, Ball AS (2003) Soil type is the primary determinant of the composition of the total and active bacterial communities in arable soils. Appl Environ Microbiol 69:1800-1809

He JZ, Shen JP, Zhang LM, Zhu YG, Zheng YM, Xu MG, Di HJ (2007) Quantitative analyses of the abundance and composition of ammonia-oxidizing bacteria and ammonia-oxidizing Archaea of a Chinese upland red soil under long-term fertilization practices. Environ Microbiol 9:2364-2374

Könneke M, Bernhard AE, de la Torre JR, Walker CB, Waterbury JB, Stahl DA (2005) Isolation of an autotrophic ammonia-oxidizing marine archaeon. Nature 437:43-546

Lam P, Jensen MM, Lavik G, McGinnis DF, Muller B, Schubert CJ, Amann R, Thamdrup B, Kuypers MMM (2007) Linking crenarchaeal and bacterial nitrification to anammox in the Black Sea. Proc Natl Acad Sci USA 104:7104-7109

Leininger S, Urich T, Schloter M, Schwark L, Qi J, Nicol GW, Prosser JI, Schuster SC, Schleper C (2006) Archaea predominate among ammonia-oxidizing prokaryotes in soils. Nature 442:806-809

Mincer TJ, Church MJ, Taylor LT, Preston C, Kar DM, DeLong EF (2007) Quantitative distribution of presumptive Archaeal and bacterial nitrifiers in Monterey Bay and the North Pacific Subtropical Gyre. Environ Microbiol 9:1162-1175

Mosier AC, Francis CA (2008) Relative abundance and diversity of ammonia-oxidizing Archaea and bacteria in the San Francisco Bay estuary. Environ Microbiol 10:3002-3016

Nicolaisen MH, Risgaard-Petersen N, Revsbech NP, Reichardt W, Ramsing NB (2004) Nitrification-denitrification dynamics and community structure of ammonia oxidizing bacteria in a high yield irrigated Philippine rice field. FEMS Microbiol Ecol 49:359-369

Park HD, Wells GF, Bae H, Criddle CS, Francis CA (2006) Occurrence of ammonia-oxidizing Archaea in wastewater treatment plant bioreactors. Appl Environ Microbiol 72:5643-5647

Prosser JI (1989) Autotrophic nitrification in bacteria. Adv Microb Physiol 30:125-181

Revsbech NP, Pedersen O, Reichardt W, Briones A (1999) Microsensor analysis of oxygen and $\mathrm{pH}$ in the rice rhizosphere under field and laboratory conditions. Biol Fertil Soils 29:379-385

Rotthauwe JH, Witzel KP, Liesack W (1997) The ammonia monooxygenase structural gene amo $A$ as a functional marker: molecular fine-scale analysis of natural ammonia-oxidizing populations. Appl Environ Microbiol 63:4704-4712

Santoro AE, Francis CA, de Sieyes NR, Boehm AB (2008) Shifts in the relative abundance of ammonia-oxidizing bacteria and Archaea across physicochemical gradients in a subterranean estuary. Environ Microbiol 10:1068-1079

Schauss K, Focks A, Leininger S, Kotzerke A, Heuer H, Thiele-Bruhn S, Sharma S, Wilke BM, Matthies M, Smalla K, Munch JC, Amelung W, Kaupenjohann M, Schloter M, Schleper C (2009) Dynamics and functional relevance of ammonia-oxidizing Archaea in two agricultural soils. Environ Microbiol 11:446-456

Shen JP, Zhang LM, Zhu YG, Zhang JB, He JZ (2008) Abundance and composition of ammonia-oxidizing bacteria and ammoniaoxidizing Archaea communities of an alkaline sandy loam. Environ Microbiol 10:1601-1611

Treusch AH, Leininger S, Kletzin A, Schuster SC, Klenk HP, Schleper C (2005) Novel genes for nitrite reductase and Amo-related proteins indicate a role of uncultivated mesophilic Crenarchaeota in nitrogen cycling. Environ Microbiol 7:1985-1995

Venter JC, Remington K, Heidelberg JF, Halpern AL, Rusch D, Eisen JA, Wu DY, Paulsen I, Nelson KE, Nelson W, Fouts DE, Levy S, Knap AH, Lomas MW, Nealson K, White O, Peterson J, Hoffman J, Parsons R, Baden-Tillson H, Pfannkoch C, Rogers YH, Smith HO (2004) Environmental genome shotgun sequencing of the Sargasso Sea. Science 304:66-74

Wang YA, Ke XB, Wu LQ, Lu YH (2009) Community composition of ammonia-oxidizing bacteria and Archaea in rice field soil as affected by nitrogen fertilization. Syst Appl Microbiol 32:27-36

Weidler GW, Dornmayr-Pfaffenhuemer M, Gerbl FW, Heinen W, Stan-Lotter H (2007) Communities of Archaea and bacteria in a 
subsurface radioactive thermal spring in the Austrian Central Alps, and evidence of ammonia-oxidizing Crenarchaeota. Appl Environ Microbiol 73:259-270

Wuchter C, Abbas B, Coolen MJL, Herfort L, Van Bleijswijk J, Timmers P, Strous M, Teira E, Herndl GJ, Middelburg JJ, Schouten S, Damste JSS (2006) Archaeal nitrification in the ocean. Proc Natl Acad Sci USA 103:12317-12322

Yang CH, Crowley DE (2000) Rhizosphere microbial community structure in relation to root location and plant iron nutrition status. Appl Environ Microbiol 66:345-351
Ying JY, Zhang LM, He JZ (2010) Putative ammonia-oxidizing bacteria and Archaea in an acidic red soil with different land utilization patterns. Environ Microbiol Reports 2:304-312

Yuan F, Ran W, Shen QR, Wang DZ (2005) Characterization of nitrifying bacteria communities of soils from different ecological regions of China by molecular and conventional methods. Biol Fertil Soils 41:22-27

Zhang LM, Wang M, Prosser JI, Zheng YM, He JZ (2009) Altitude ammonia-oxidizing bacteria and Archaea in soils of Mount Everest. FEMS Microbiol Ecol 70:208-217 